\title{
Research SAP Acceptance Rate Analysis At PT. Pindodeli Uses The Technology Acceptance Model (TAM) Approach
}

\author{
M. Wahidin ${ }^{\mathrm{a} *}$ Jajang $^{\mathrm{b}}$, Anggi Elanda ${ }^{\mathrm{c}}$, Charlie Khowirantio L. S. ${ }^{\mathrm{d}}$ \\ a, b, c,dSTMIK Rosma, Jl. Kertabumi No. 622, Karawang 41311, Indonesia \\ *Corresponding author: m.wahidin@dosen.rosma.ac.id
}

\begin{abstract}
This study discusses the analysis of the SAP acceptance rate at PT Pindodeli using the TAM approach. The purpose of this study was to determine the acceptance of the SAP system for Pindodeli employees and to determine the factors that affect the acceptance of the SAP system for PT Pindodeli employees. The method used in this research is the Technology Acceptance Model (TAM). The population in this study were 130 employees of PT Pindodeli from 6 Units / Sections, namely Finished Goods, IT, Financing, Logistics, Customer Service, and Purchasing. The sampling technique used by researchers is probability sampling and uses a descriptive approach. The total respondents who got were 61 out of 130 employees. Calculation of data carried out in this study is smart PLS. Hypothesis testing in this study was conducted to test the effect of system service usability and ease of use. The research results prove that usability has a positive and significant effect on SAP system acceptance and ease of use has a positive and significant effect on SAP system acceptance.
\end{abstract}

Keywords : SAP Acceptance; TAM; Usability Satisfaction; Usability

\begin{abstract}
Abstrak
Penelitian ini membahas tentang analisis tingkat penerimaan SAP di PT Pindodeli dengan menggunakan pendekatan TAM. Tujuan penelitian ini adalah untuk mengetahui penerimaan sistem SAP bagi karyawan Pindodeli dan untuk mengetahui faktor-faktor yang mempengaruhi penerimaan sistem SAP bagi karyawan PT Pindodeli. Metode yang digunakan dalam penelitian ini adalah Technology Acceptance Model (TAM). Populasi dalam penelitian ini adalah 130 karyawan PT Pindodeli dari 6 Unit / Bagian yaitu Barang Jadi, IT, Pembiayaan, Logistik, Layanan Pelanggan, dan Pembelian. Teknik pengambilan sampel yang digunakan peneliti adalah probability sampling dan menggunakan pendekatan deskriptif. Total responden yang didapat sebanyak 61 dari 130 karyawan. Perhitungan data yang dilakukan dalam penelitian ini adalah PLS pintar. Pengujian hipotesis dalam penelitian ini dilakukan untuk menguji pengaruh kegunaan layanan sistem serta kemudahan penggunaan. Hasil penelitian membuktikan bahwa usability berpengaruh positif dan signifikan terhadap penerimaan sistem SAP dan kemudahan penggunaan berpengaruh positif dan signifikan terhadap penerimaan sistem SAP.
\end{abstract}

Keywords : Kegunaan; Kepuasaan Penggunaan; Penerimaan SAP; TAM

\section{Pendahuluan}

Di Indonesia banyak berbagai sistem ERP controlling dan monitoring yang digunakan oleh berbagai perusahaan. Salah satu system yang digunakan adalah SAP. Pada saat ini sistem controlling dan monitoring sangat dibutuhkan oleh perusahaan dan hampir seluruh dunia sudah menggunakan Controlling and Monitoring system untuk melakukan keluar masuk barang atau kegiatan bisnis lainnya sehingga tidak lagi dengan cara manual.

SAP sekarang ini mendapat perhatian lebih dari konsumen atau karyawan dalam melakukan pengendalian sebagai alternative dari mengecek semua secara manual. Kegiatan yang dilakukan secara manual menimbulkan 
kesalahan atau memakan waktu yang lama. Penggunaan sistem SAP memberikan kepraktisan, kemudahan, kecepatan serta memberikan kenyamanan dalam melakukan proses bisnis.

SAP (System Application and Product in data processing) merupakan software Enterprise Resources Planning (ERP), yaitu suatu tools IT dan manajemen untuk membantu perusahaan merencanakan dan melakukan kegiatan operasionalnya secara lebih efisien dan efektif. SAP terdiri dari sejumlah modul aplikasi yang mempunyai kemampuan mendukung semua transaksi yang perlu dilakukan suatu perusahaan dan tiap aplikasi bekerja secara berkaitan satu dengan yang lainnya. Semua modul aplikasi di SAP dapat bekerja secara terintegrasi/terhubung yang satu dengan lainnya.

SAP ERP adalah software ERP terkemuka didunia, yang dikembangkan oleh SAP AG. SAP ERP adalah perangkat lunak yang terintegrasi, memungkinkan informasi untuk dibagi diantara bidang fungsional. Masing-masing departemen fungsional membutuhkan informasi dari departemen lain, yang dibuat mungkin dengan sistem terpadu. [1]

Ada beberapa modul atau T-Code yang mengikat dari sistem SAP seperti adanya modul yang digunakan untuk bagian financing, modul bagian purchasing, modul untuk bagian gudang, modul untuk bagian transportasi, modul bagian customer service, modul untuk bagian IT dan yang lainnya yang digunakan secara terintegrasi/terhubung satu sama lain.

PT PindoDeli Pulp \& Paper Mills Merupakan salah satu perusahaan yang menggunakan sistem SAP. Sistem SAP tersebut dapat membantu karyawan dalam melakukan pekerjaan dan meningkatkan pengetahuan karyawan tentang sebuah sistem tersebut. Namun ada hal yang harus dicermati dalam menggunakan sistem SAP tersebut yaitu adanya factor yang menjadi penghalang keberhasilan penggunaan SAP seperti masalah otoritas dalam penggunaan SAP, akses yang tidak bisa semua admin menggunakan, infrastruktur, ruang lingkup, dan yang lain.

Beberapa peneliti terdahulu mengungkapkan bahwa dalam mengukur tingkat penerimaan suatu teknologi dapat menggunakan pendekatan TAM (Technologi Acceptance Model) seperti yang di ungkapkan oleh Nurmaini yang menganalisis penerimaan sistem e-Learning dengan model TAM yang bertujuan untuk mengetahui tingkat kemanfaatan e-Learning pada siswa SMK di Pekanbaru [2]. Model TAM dikembangkan oleh Davis yang mengadaptasi model Theory of Reasoned Action (TRA). Model ini adalah teori sistem informasi yang membuat model tentang bagaimana pengguna mau menerima dan menggunakan teknologi. [3]

Berdasarkan hasil uraian di atas dan berdasarkan penelitian terdahulu menarik penulis untuk meneliti tingkat penerimaan sistem SAP di PT Pindodeli menggunakan pendekatan TAM dalam rangka meningkatkan tingkat penerimaan aplikasi SAP sebagai pendukung dalam pengelolaan dan controlling produktivitas PT Pindodeli.

\section{Tinjauan Pustaka}

\subsection{Technology Acceptance Model (TAM)}

Technology Acceptance Model (TAM) Diperkenalkan pertama kali oleh Davis 1989. TAM dibuat khusus untuk permodelan adopsi pengguna sistem informasi [4]. Menurut (Jogiyanto, 2008;111) dalam jurnal [5] Technology Acceptance Model (TAM) merupakan salah satu teori tentang penggunaan sistem teknologi informasi yang dianggap sangat berpengaruh dan umumnya digunakan untuk menjelaskan penerimaan individual terhadap penggunaan sistem teknologi informasi. Para peneliti sistem informasi telah mengadopsi teori tindakan yang beralasan (Theory of Reasoned Action) dari Fishbein \&Azjen (1975) yaitu suatu teori yang berhubungan dengan sikap dan perilaku individu dalam melaksanakan kegiatan atau tindakan yang beralasan dalam kontek penggunaan TI.

\subsection{Enterprise Resource Planning (ERP)}

Enterprise Resource Planning (ERP) Adalah perangkat lunak utama dari perusahaan yang bekerja untuk mengintegrasikan informasi yang ada disemua bidang bisnis yang memiliki tujuan untuk dapat merencanakan dan mengelola semua sumber daya yang tersedia bagi suatu persuhaan sehingga semua bisnis area dalam persuahaan bisa berjalan dengan baik [1]. Sedangkan menurut Presetyaningrum (2020) [6] sistem ERP adalah sebuah sistem informasi perusahaan yang dirancang untuk mengkoordinasi semua sumber daya, informasi dan aktifitas yang diperlukan untuk proses bisnis secara lengkap. 
Sistem ERP Adalah sistem informasi yang diperuntukkan bagi perusahaan manufaktur maupun jasa yang berperan mengintegrasikan dan mengotomasikan proses bisnis yang berhubungan dengan aspek operasi, produksi, maupun distribusi di perusahaan.

\subsection{System Application and Product (SAP)}

SAP Adalah sistem yang digunakan untuk mendukung kegiatan atau aktivitas yang berjalan dalam suatu organisasi secara otomatis sehingga efisiensi dan produktifitas bisa meningkat secara efitisien. Menurut (Seto, 2013) dalam jurnal [7] SAP terdiri dari sejumlah modul/aplikasi yang mempunyai kemampuan mendukung semua transaksi yang perlu dilakukan suatu perusahaan dan tiap aplikasi bekerja secara berkaitan satu dengan yang lainnya. Menurut [8] SAP dilengkapi tiga buah modul besar yaitu modul finance, untuk mengurus hal yang berkaitan dengan keuangan perusahaan, Logistic untuk mengurus segala hal tentang barang baik asset bergerak ataupun tetap, dan Human Resource yang digunakan untuk mengurus segala hal mengenai Personalia.

\section{Metode}

Penelitian ini menggunakan jenis penelitian kuantitatif yaitu pendekatan deskriptif. Desain penelitian akan menjelaskan bagaimana jalur pemikirian yang dirancang berdasarkan kegiatan peneliti. Penelitian kuantitatif biasanya menggunakan desain eksplanasi, dimana objek telaahan penelitian eksplanasi (explanatory research) adalah untuk menguji hubungan amtar-variabel yang dihipotesiskan [9].

Model penelitian ini dilakukan dengan metode TAM. Teknik Pengumpulan data yang dilakukan dalam penelitian ini adalah dengan melakukan penyebaran kuisioner kepada karyawan PT Pindodeli di 6 Unit/bagian. Paritisipan dalam penelitian ini adalah Karyawan PT Pindodeli baik Pindodeli 1, 2 ataupun 3. Populasi dari penelitian ini adalah para pengguna SAP yang terdiri dari 6 Unit/Bagiam yaitu Finished Goods, IT, Financing, Purchasing, Logistic, dan Customer service. Total partisipan yang ada sebanyak 130 karyawan. Sampel yang didapat dari penelitian adalah sebanyak 61 responden. Pengambilan sampel adalah metode sistematis untuk pemilihan subjek yang akan diteliti. Pengambilan sampel dalam penelitian ini menggunakan teknik probality sampling, yaitu teknik pengambilan sampel yang sudah diketahui populasinya. Pada penelitian ini peneliti memilih teknik pengumpulan data dengan menggunakan Propotionate stratified random sampling. Peneliti mengambil sample sebanyak 61 Karyawan dari total 130 karyawan pengguna SAP di 6 Unit/bagian.

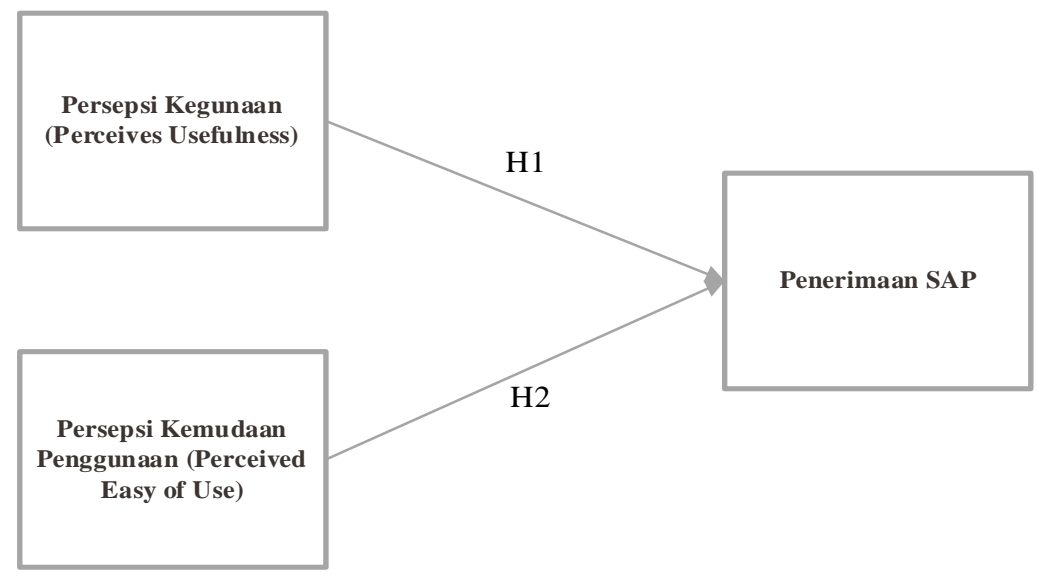

Technology Acceptance

Model

Gambar 1. Model Penelitian

Berdasarkan model penelitian diatas, maka dapat ditetapkan hipotesis dari penelitian ini adalah sebagai berikut:

- H1. Kegunaan berpengaruh terhadap penerimaan layanan Sistem ERP.

- H2. Kemudahan pengunaan berpengaruh terhadap penerimaan layanan Sistem ERP. 


\section{Hasil dan Pembahasan}

\subsection{Karakteristik Responden}

Subyek dalam penelitian ini adalah Karyawan PT Pindodeli yang menggunakan SAP dalam pekerjaannya. Pada penelitian ini dipilih responden yaitu para karyawan yang menggunakan sistem SAP di PT Pindodeli dari 6 Unit/Bagian seperti IT, Purchasing, Finished Goods, Purchasing, Customer Service, dan Logistic sebagai populasi dari responden, karena diharapkan mereka sudah memiliki pengetahuan tentang SAP dan tools lainnya sehingga dapat membantu peneliti memberikan data yang bisa di pertanggung jawabkan. Karakteristik responden dalam penelitian ini terbagi menjadi dua, yaitu karakteristik responden berdasarkan jenis kelamin dan karakteristik responden berdasarkan unit/bagian kerja.

Tabel 1. Karakteristik Responden berdasarkan Jenis Kelamin

\begin{tabular}{lcc}
\hline \multicolumn{1}{c}{ Jenis Kelamin } & Jumlah & Presentase \\
\hline Pria & 35 & $57,4 \%$ \\
\hline Wanita & 26 & $42,6 \%$ \\
\hline Total & 61 & $100,0 \%$ \\
\hline
\end{tabular}

Berdasarkan Tabel 1 dapat dilihat responden Pria lebih banyak yaitu sebanyak 35 responden atau sebesar $57,4 \%$ dan sisanya responden wanita sebanyak 26 responden atau sebesar $42,6 \%$ dan total keseluruhan 61 responden.

Tabel 2. Karakteristik Responden berdasarkan Unit/Bagian

\begin{tabular}{lcc}
\hline \multicolumn{1}{c}{ Unit/Bagian } & Jumlah & Presentase \\
\hline Finished Goods & 28 & $45,9 \%$ \\
\hline Financing & 5 & $8,2 \%$ \\
\hline Logistic & 9 & $14,8 \%$ \\
\hline IT & 5 & $8,2 \%$ \\
\hline Customer Service & 7 & $11,5 \%$ \\
\hline Purcchasing & 7 & $11,5 \%$ \\
\hline Total & 61 & $100,0 \%$ \\
\hline
\end{tabular}

Berdasarkan Tabel 2 dapat dilihat responden dari berbagai unit/Bagian beserta jumlah presentasenya, diantaranya ada Finished Goods berjumlah 28 responden atau sebesar 45,9\%, kemudian dari Financing sebanyak 5 responden atau sebesar 8,2\%, Logisctik sebanyak 9 responden atau sebesar 14,8\%, IT sebanyak 5 respnden atau sebesar $8,2 \%$, Customer Service sebanyak 7 responden atau sebesar $11,5 \%$, da nada purchasing sebanyak 7 responden atau sebesar $11,5 \%$.

\subsection{Uji Validitas}

Menurut Chin (1998), suatu kolerasi dapat dikatakan memenuhi validitas konvergen apabila memiliki nilai loading sebesar lebih besar dari 0,5 [10]. Selain dengan melihat nilai loading factor masing-masing indikator, validitas konvergen juga dinilai dari nilai AVE setiap konstruk, model PLS dinyatakan telah memenuhi validitas konvergen jika nilai AVE setiap konstruk >0,5 [11].

Tabel 3. Nilai Loading Factor dan AVE

\begin{tabular}{|c|c|c|c|c|}
\hline Variabel & Pernyataan & Kode & Loading & AVE \\
\hline \multirow[t]{3}{*}{$\begin{array}{l}\text { Kegunaan } \\
\text { (KG) }\end{array}$} & $\begin{array}{l}\text { Menggunakan SAP dalam pekerjaan, } \\
\text { memungkinkan saya untuk } \\
\text { menyelesaiakn tugas dengan lebih cepat }\end{array}$ & KG 1 & & \multirow{3}{*}{0.602} \\
\hline & $\begin{array}{l}\text { Menggunakan SAP dalam pekerjaan, } \\
\text { memungkinkan saya mendapatkan reward }\end{array}$ & $\mathrm{KG} 2$ & 0.756 & \\
\hline & $\begin{array}{l}\text { Menggunakan SAP dalam pekerjaan, } \\
\text { secara efektif menyelesaikan tugas saya }\end{array}$ & KG 3 & 0.708 & \\
\hline
\end{tabular}




\begin{tabular}{|c|c|c|c|c|}
\hline Variabel & Pernyataan & Kode & Loading & AVE \\
\hline & $\begin{array}{l}\text { Menggunakan SAP dalam pekerjaan, } \\
\text { memungkinkan saya mencapai target } \\
\text { pekerjaan saya }\end{array}$ & KG 4 & 0.765 & \\
\hline & $\begin{array}{l}\text { Menggunakan SAP dalam pekerjaan, } \\
\text { memungkinkan saya mencapai tujuan } \\
\text { saya tepat waktu }\end{array}$ & KG 5 & 0.819 & \\
\hline & $\begin{array}{l}\text { Menggunakan SAP dalam pekerjaan, } \\
\text { memungkinkan saya berprestasi }\end{array}$ & KG 6 & 0.840 & \\
\hline & $\begin{array}{l}\text { Menggunakan SAP dalam pekerjaan, } \\
\text { meningkatkan kinerja saya }\end{array}$ & KG 7 & 0.718 & \\
\hline & $\begin{array}{l}\text { Menggunakan SAP dalam pekerjaan, } \\
\text { meningkatkan produktivitas saya dalam } \\
\text { bekerja }\end{array}$ & KG 8 & 0.806 & \\
\hline \multirow{6}{*}{$\begin{array}{l}\text { Kemudahan } \\
\text { Penggunaan } \\
\text { (KP) }\end{array}$} & SAP sangat mudah untuk dipelajari & KP 1 & 0.759 & \multirow{6}{*}{0.637} \\
\hline & Modul SAP sangat mudah di pahami & KP 2 & 0.774 & \\
\hline & $\begin{array}{l}\text { Untuk mempelajari modul SAP, saya } \\
\text { tidak membutuhkan waktu yang lama }\end{array}$ & KP 3 & 0.710 & \\
\hline & SAP sangat mudah dioperasikan & KP 4 & 0.844 & \\
\hline & Modul-modul SAP mudah dioperasikan & KP 5 & 0.871 & \\
\hline & $\begin{array}{l}\text { Menu - menu pada SAP tidak sulit } \\
\text { digunakan }\end{array}$ & KP 6 & 0.820 & \\
\hline \multirow[t]{3}{*}{$\begin{array}{l}\text { Penerimaan } \\
\text { sistem SAP } \\
(\mathbf{P N})\end{array}$} & $\begin{array}{l}\text { Saya mengkoneksikan SAP dengan } \\
\text { beberapa sistem sebagai media untuk } \\
\text { pengontrolan }\end{array}$ & PN 1 & 0.878 & \multirow{3}{*}{0.696} \\
\hline & $\begin{array}{l}\text { Saya menggunakan SAP untuk } \\
\text { melakukan kegiatan transaksi }\end{array}$ & PN 2 & 0.818 & \\
\hline & $\begin{array}{l}\text { Hampir semua aktivitas saya } \\
\text { menggunakan SAP }\end{array}$ & PN 5 & 0.804 & \\
\hline
\end{tabular}

Pada tabel 3 dapat ketahui bahwa beberapa item pernyataan dari masing masing variabel telah memenuhi persyaratan uji validitas konvergen. Persyaratan untuk memenuhi uji validitas karena memiliki loading factor $>0.5$ dan juga nilai AVE untuk setiap variable memiliki nilai diatas 0.5. Dengan demikian, dalam penelitian ini seluruh indikatornya dapat dinyatakan valid.

\subsection{Uji Reliabilitas}

Pengujian validitas pada penelitian ini dengan cara menghitung nilai composite reliability. Menurut Sarwono dan Narimawati (2015:18) menyatakan bahwa suatu variabel laten dapat dikatakan mempunyai realibilitas yang baik apabila nilai composite reliability lebih besar dari 0,7 [10].

Tabel 4. Nilai Composite Reliability

\begin{tabular}{lc}
\hline \multicolumn{1}{c}{ Variabel } & Composite Reliability \\
\hline Kegunaan (KG) & 0.913 \\
\hline Kemudahan Penggunaan (KP) & 0.913 \\
\hline Penerimaan sistem SAP (PN) & 0.873 \\
\hline
\end{tabular}

Pada tabel 4 dapat dilihat bahwa semua variabel yang digunakan dalam penelitian ini dinyatakan reliable dikarenakan semua variabel ini memiliki nilai Composite reliability $>0.7$.

\subsection{Pengujian Inner Model}

Pengujian inner model meliputi uji signifikansi pengaruh langsung dan tidak langsung serta pengukuran besarnya pengaruh variabel eksogen terhadap variabel endogen [11]. Pengujian inner model dilakukan dengan menghitung nilai R-square. 
Tabel 5. Nilai R-Square

\begin{tabular}{cc}
\hline Variabel & R Square \\
\hline Penerimaan sistem SAP $($ PN $)$ & 0.537 \\
\hline
\end{tabular}

Pada tabel 5 dapat dilihat bahwa variabel penerimaan memiliki nilai R-Square sebesar 0.537 yang berarti variabel persepsi kegunaan dan kemudahan pengguna mempengaruhi variabel penerimaan sebesar $53.7 \%$ dan sisanya sebesar $46.3 \%$ dipengaruhi oleh variabel lain.

\subsection{Uji Hipotesis}

Pada pengujian hipotesis dilakukan dengan menghitung nilai path coefficients dan $t$-statistic. Path Coefficients dinyatakan positif jika memiliki nilai $>0.1$ dan dinyatakan negative jika memiliki nilai $<0.1$. Nilai T-Statistic dapat dinyatakan signifikan jika memiliki nilai $>1.96$ dan dinyatakan tidak signifikan jika memiliki nilai <1.96. Hasil pengujian hipotesis dapat dilihat pada tabel dibawah ini.

Tabel 6. Path Coefficients dan T-Statistics

\begin{tabular}{lcccll}
\hline & Hipotesis & Path Coefficients & T-Statistic & \multicolumn{2}{c}{ Keterangan } \\
\hline H1 & $\mathrm{KG} \longrightarrow \mathrm{PN}$ & $(+) 0.465$ & 3.253 & $\begin{array}{l}\text { H1 Memiliki pengaruh positif dan } \\
\text { signifikan }\end{array}$ \\
\hline H2 & $\mathrm{KP} \longrightarrow \mathrm{PN}$ & $(+) 0.341$ & 2.345 & $\begin{array}{l}\text { H2 Memiliki pengaruh positif dan } \\
\text { signifikan }\end{array}$ \\
\hline
\end{tabular}

\section{a. Kegunaan (KG) Berpengaruh Positif terhadap Penerimaan sistem SAP (PN)}

Hasil dari pengujian hipotesis pertama (H1) menunjukkan yaitu Kegunaan berpengaruh positif terhadap Penerimaan sistem SAP (PN). Hal ini dapat dilihat dalam tabel 4.9 bahwa Kegunaan (KG) memiliki nilai T-Statistic yaitu sebesar 3.253 yang dinyatakan signifikan karena diatas $>1.96$ dan memiliki Path Coefficients sebesar 0.465 yang dinyatakan positif karena diatas nilai $>0.1$.

b. Kemudahan Penggunaan (KP) berpengaruh Positif terhadap penerimaan sistem SAP (PN)

Hasil dari pengujian hipotesis pertama (H2) menunjukkan yaitu Kemudahan Penggunaan berpengaruh positif terhadap Penerimaan sistem SAP (PN). Hal ini dapat dilihat dalam tabel 4.9 bahwa Kemudahaan Penggunaan (KP) memiliki nilai T-Statistic yaitu sebesar 2.345 yang dinyatakan signifikan karena diatas $>1.96$ dan memiliki Path Coefficients sebesar 0.341 yang dinyatakan positif karena diatas nilai >0.1.

\section{Kesimpulan dan Saran}

\subsection{Kesimpulan}

Berdasarkan penelitian yang telah dilakukan terhadap pengguna SAP yang terdiri dari 6 Unit/Bagiam yaitu Finished Goods, IT, Financing, Purchasing, Logistic, dan Customer service, menerima adanya sistem SAP pada PT. Pindodeli. Penerimaan tersebut berdasarkan hasil analisis yang dilakukan dengan pengujian hipotesis penelitian. Hasil pengujian hipotesis pertama $(\mathrm{H} 1)$ dan hipotesis kedua $(\mathrm{H} 2)$ secara berturut-turut menujukkan hasil yang signifikan karena telah menenuhi syarat nilai $t$-statistic $>1.96$ dan nilai path coefficient $>0,1$. Hasil pengujian memberikan hasil konstribusi implikasi yaitu persepsi Kegunaan dan Kemudahan Penggunaan berpengaruh positif terhadap Penerimaan sistem SAP PT. Pindodeli. Faktor kemudahan yang dirasakan oleh pengguna SAP sangat mempengaruhi pengguna SAP untuk manfaatkan dan menggunakan serta menerima sistem SAP pada PT. Pindodeli.

\subsection{Saran}

Berdasarkan hasil penelitian ini, maka terdapat beberapa saran yang di tuangkan oleh peneliti, yaitu:

a. Untuk peneliti selanjutnya diharapkan agar dapat melakukan penelitian sistem SAP lebih banyak bagian/Unit.

b. Untuk PT Pindodeli semoga tetap menggunakan sistem seperti SAP ini dan disertai sistem sistem lainnya yang mendukung jalannya sistem SAP ini sehingga karyawan bisa dengan gampang melakukan pengecekan atau transaksi lainnya. 
c. Bagi referensi selanjutnya, diharapkan dapat mengembangkan penelitian ini menjadi lebih baik dan diharapkan bisa menjadi refensi untuk kedepannya.

\section{References}

[1] Y. Putri, A. Y. Ridwan, and R. W. Witjaksono, "Pengembangan Sistem Informasi Berbasis Enterprise Resource Planning Modul Purchasing (MM-PUR) Pada SAP Dengan Metode Asap Di PT. Unggul Jaya Sejahtera," J. Rekayasa Sist. Ind., vol. 3, no. 04, p. 108, 2017, doi: 10.25124/jrsi.v3i04.279.

[2] N. Dalimunthe and H. Wibisono, "ANALISIS PENERIMAAN SISTEM e-learning SMK LABOR PEKANBARU DENGAN MENGGUNAKAN TECHOLOGY ACCEPTANCE MODEL (TAM)," J. Sains dan Teknol. Ind., vol. 11, no. 1, pp. 111-117, 2014.

[3] H. Ramadhani and S. Monalisa, "Analisis Penerapan Sistem Informasi Pengelolaan Nilai Raport Menggunakan Metode TAM," J. Ilm. Rekayasa dan Manaj. Sist. Inf., vol. 3, no. 2, pp. 65-69, 2017.

[4] A. Rizal, "Analisis Penerapan Project Management Information System (PMIS) Menggunakan Metode Technology Acceptance Model (TAM) Studi Kasus PT. INDOSAT, Tbk," J. Telekomun. dan Komput., vol. 5, no. 1, p. 1, 2017, doi: 10.22441/incomtech.v5i1.1131.

[5] Saras Mareta Ratri, “Analisis Faktor-Faktor Yang Memengaruhi Penggunaan E-Learning Moodle Oleh Guru Smk Negeri 2 Yogyakarta Dengan Pendekatan Technology Acceptance Model (Tam),” Skripsi, pp. 1-129, 2016.

[6] E. and others Prasetyaningrum, "Pengembangan Teknologi ERP Modul Human Resources Management Studi Kasus Aquarius Boutique Hotel Sampit," IKRA-ITH Inform. J. Komput. dan Inform., vol. 5, no. 2, pp. 67--74, 2020.

[7] F. Rahman, "Evaluasi Penerapan Enterprise Resources Planning (Erp) Terhadap Penyajian Laporan Keuangan (Studi Kasus Di Pt. Surya Citra Televisi)," Kreat. J. Ilm. Prodi Manaj. Univ. Pamulang, vol. 6, no. 3, p. 109, 2018, doi: 10.32493/jk.v6i3.y2018.p109-126.

[8] S. O. Zayin, "Evaluasi Penerapan Modul Manajemen Material (MM) SAP Untuk Pengadaan Material Di PT.Petrokimia Gresik," no. Mm, p. 107, 2017.

[9] M. Mulyadi, "Penelitian Kuantitatif Dan Kualitatif Serta Pemikiran Dasar Menggabungkannya," J. Stud. Komun. dan Media, vol. 15, no. 1, p. 128, 2013, doi: 10.31445/jskm.2011.150106.

[10] A. Andi and Y. Ani, "Analisis Faktor Siswa Mengunakan M- Learning Dengan Metode Structural Partial Least Square," Inti Nusa Mandiri, vol. 14, no. 2, pp. 133-138, 2019.

[11] M. Asbari, P. B. Santoso, and A. Purwanto, "Pengaruh Kepemimpinan dan Budaya Organisasi Terhadap Perilaku Kerja Inovatif pada Industri 4.0," Jim UPB, vol. 8, no. 1, pp. 7-15, 2019, doi: ttps://doi.org/10.33884/jimupb.v8i1.1562. 